\title{
ANALISIS KONSENTRASI MINYAK ATSIRI DARI SEREH SEBAGAI ADITIF DALAM PEMBUATAN LOTION ANTI NYAMUK
}

\author{
Rini Siskayanti' ${ }^{1)}$, Muhamad Engkos Kosim²), Dedi Andika Saputra ${ }^{3)}$ \\ ${ }^{1)}$ Program Studi S3 Ilmu Teknik, Fakultas Teknik, Universitas Sriwijaya \\ ${ }^{2,3)}$ Fakultas Teknik, Universitas Muhammadiyah Jakarta \\ email: 03013622126025@ @student.unsri.ac.id
}

\begin{abstract}
Abstrak
Tanaman sereh wangi (Cymbopongon nardus L.) merupakan sumber minyak atsiri yang diperoleh dengan cara ekstraksi. Sereh wangi memiliki banyak manfaat. Minyak Atsiri sereh memiliki banyak keunggulan untuk pembuatan lotion anti nyamuk diantaranya baunya yang menyengat dan bersifat alami, sehingga aman untuk kulit. Penelitian ini untuk menentukan konsentrasi terbaik dari minyak atsiri sereh. Penelitian ini menggunakan metode ekstrasi maserasi dengan mencampurkan simplisia batang sereh dengan air kemudian diaduk, lalu didiamkan selama beberapa waktu. Analisis yang dilakukan antara lain yaitu uji viskositas, uji bau citronella, uji $\mathrm{pH}$ dan uji iritasi. Hasil penelitian menunjukkan bahwa dari variasi konsentrasi minyak atsiri $(0 \%, 0,5 \%, 1 \%, 1,5 \%, 2 \%)$ hasil terbaiknya adalah formula $\mathrm{V}$ yaitu dengan konsentrasi $2 \%$, dan aman untuk kulit atau tidak panas saat digunakan, dengan $\mathrm{pH} 7,2$, serta berbau menyengat khas citronella. Dengan variasi konsentrasi minyak atsiri itu berpengaruh sangat nyata terhadap viskositas lotion.
\end{abstract}

\section{Kata Kunci :}

Ekstraksi, konsentrasi minyak atsiri, lotion anti nyamuk

\section{PENDAHULUAN}

Kehidupan kita sebagai masyarakat Indonesia tidak dapat di pisahkan dari keberadaan nyamuk. Salah satu bahaya yang di sebabkan oleh gigitan nyamuk adalah berbagai macam penyakit yang bahkan hingga dapat menyebabkan kematian. Upaya-upaya untuk mencegah penyakit-penyakit yang disebabkan oleh nyamuk, di antaranya dengan memasang kawat kasa pada jendela rumah, memasang kelambu tidur, menggunakan lotion anti nyamuk, semprot, bakar, dan elektrik. Lotion anti nyamuk merupakan produk berbahan kimia yang telah banyak di gunakan. Produk ini bersifat toksin, meninggalkan bau, dapat menyebabkan iritasi pada kulit, resistensi serangga, pencemaran lingkungan, dan meracuni mahluk hidup lain yang bukan sasaran. Hal-hal semacam itu dapat di atasi salah satunya dengan menggunakan insektisida alami yang umumnya berasal dari tumbuhan. Tumbuhan dianggap memiliki tingkat keamanan yang lebih tinggi karena sifatnya yang mudah terurai di alam sehingga tidak menimbulkan bahaya residu yang berat dan tentunya lebih selektif dengan tidak ikut meracuni mahluk hidup dan lingkungan lain yang bukan sasaran. Beberapa macam tumbuhan yang dapat digunakan sebagai insektisida alami antara lain tanaman tapak dara, selasih, zodia, lidah buaya, dan sereh. Tanaman sereh memiliki banyak keunggulan diantaranya bau yang menyengat yang tidak disukai nyamuk.

Tujuan dari penelitian ini adalah menentukan konsentrasi optimum minyak atsiri dari hasil ekstraksi batang sereh yang akan digunakan pada pembuatan lotion anti nyamuk. Pada penelitian kali ini metode yang diambil adalah metode maserasi, selain mendapatkan aroma khas minyak atsiri dari sereh lebih kuat juga pembuatanya tidak terlalu rumit. 


\section{Tanaman Sereh}

Tanaman sereh wangi termasuk golongan rumput-rumputan yang disebut Andropogon nardus atau Cymbopogon nardus. Genus ini meliputi hampir 80 spesies, ekonomi dalam dunia perdagangan. Minyak sereh wangi mengandung Sitronellal (32-45\%), Geraniol ( $12-18 \%$ ), Sitronellol (12-15\%), Geraniol Asetat (3-8\%), Sitronellol Asetat (2-4\%), L-Limonene (2 $-5 \%$ ), Elenol dan Sekswiterpene lain $(2-5 \%)$ dan Elemen dan Cadinene (2-5\%) (Ketaren, 2008). Tanaman sereh wangi terdiri dari dua spesies, yaitu Cymbogon nardus L. dan Lenabatu dan Cymbopogon nardus $L$ atau dikenal dengan nama Mahapengiri (Fitriyani, 2013). Sereh wangi (Cymbopogon nardus L) menghasilkan minyak atsiri yang dikenal sebagai Citronella oil. Minyak citronella mengandung dua senyawa penting yaitu Sitonelal dan Geraniol (Cassel, 2006). Senyawa Sitronelal dan Geraniol berfungsi sebagai pengusir nyamuk, tetapi belum diketahui pada konsentrasi berapa sereh wangi efektif untuk menolak gigitan nyamuk. Senyawa citronelal berperan sebagai bahan insektisida yang bekerja sebagai antifeedant dan repellent (pengusir dan penghambat serangga) (Specos , 2006). Limbah dari sereh wangi (Cymbopogonnardus L) Juga dapat menolak serangga Lophobarispiperis yang merupakan salah satu hama tanaman lada karena kandungan bahan aktif di dalam limbah tersebut (Usmiati, 2015).

\section{Lotion}

Lotion merupakan suatu emulsi. Emulsi adalah suatu tetes cairan yang terdispersi dalam cairan yang lainya dan dapat dilihat dibawah microskop atau emulsi adalah suatu system heterogen terdiri dari dua cairan yang tidak bercampur, yang satu terdispersi yang lain dalam bentuk tetes kecil logam dalam arang yang menutupi pori-pori. Faktor faktor yang mempengaruhi pembentukan emulsi diantaranya, suhu, waktu pengadukan, dan kecepatan pengadukan (Ayu,2011). Fungsi utama lotion untuk perawatan kulit adalah sebagai pelembut (emolien).

\section{Ekstraksi}

Ekstraksi adalah suatu metode operasi yang digunakan dalam proses pemisahan suatu komponen dari campurannya dengan menggunakan sejumlah massa bahan (solven) sebagai tenaga pemisah.

Dibidang industri, ekstraksi sangat luas penggunaanya terutama jika larutan yang akan dipisahkan terdiri dari komponen-komponen

1. Mempunyai sifat penguapan relative yang rendah

2. Mempunyai titik didih yang berdekatan

3. Sensitif terhadap panas

4. Merupakan campuran azeotrope

Macam-macam Ekstraksi adalah Ekstraksi Maserasi, Ekstraksi Perkolasi, Ekstraksi Soxheltasi, dan Ektraksi Refluks. Sedangkan faktor-faktor yang mempengaruhi Ekstraksi yaitu : Ukuran bahan, Rasio pelarut dan bahan baku, Difusi, pH berperan dalam selektifitas, Suhu, Pelarut, dan Waktu ekstraksi. Perbandingan metode ekstraksi dapat dilihat pada tabel dibawah ini : 
Tabel 1. Perbandingan Metode Ekstraksi

\begin{tabular}{|l|l|l|}
\hline $\begin{array}{c}\text { Metode } \\
\text { Ekstraksi }\end{array}$ & \multicolumn{1}{|c|}{ Keuntungan } & \multicolumn{1}{|c|}{ Kerugian } \\
\hline Maserasi & $\begin{array}{l}\text { Biaya Murah, Peralatan yang } \\
\text { digunakan sederhana, Memiliki } \\
\text { aroma minyak atsiri yang lebih kuat }\end{array}$ & $\begin{array}{l}\text { Memerlukan waktu yang cukup lama, } \\
\text { Pengontrolan dan pengadukan harus } \\
\text { sering dilakukan }\end{array}$ \\
\hline Perkolasi & $\begin{array}{l}\text { Dapat meningkatkan derajat } \\
\text { perbedaan konsentrasi, Hasil } \\
\text { minyak atsiri lebih murni }\end{array}$ & $\begin{array}{l}\text { Banyak minyak atsiri yg terbuang karena } \\
\text { penguapan, Suhu sulit di kontrol }\end{array}$ \\
\hline Soxheltasi & $\begin{array}{l}\text { Suhu mudah dikontrol, Hasil } \\
\text { minyak atsiri lebih murni }\end{array}$ & $\begin{array}{l}\text { Biaya relatif mahal. Memerlukan } \\
\text { penyaringan hasil ekstrak yang berulang } \\
\text { kali, Banyak minyak atsiri yg terbuang } \\
\text { karena penguapan }\end{array}$ \\
\hline Refluks & $\begin{array}{l}\text { Hasil minyak atsiri lebih murni } \\
\text { karena hasil filtrat di pekatkan lagi } \\
\text { dengan metode destilasi }\end{array}$ & $\begin{array}{l}\text { Harus sering mengganti cairan penyaring, } \\
\text { Proses pemekatan hasil fitrat terlalu } \\
\text { panjang karena harus menggunakan 2 } \\
\text { metode }\end{array}$ \\
\hline
\end{tabular}

\section{Penyulingan Minyak Atsiri}

Agar minyak atsiri yang dihasilkan memiliki kemurnian yang optimum maka dilakukan penyulingan terhadap larutan hasil ekstraksi tersebut. Ada beberapa metode penyulingan diantaranya :

1. Penyulingan dengan air (Water destilasion)

Pada sistem penyulingan dengan air, bahan yang akan disuling langsung berkontak dengan air mendidih. Keuntungan dari penggunaan sistem penyulingan ini adalah karena sistem ini baik digunakan untuk menyuling bahan yang berbentuk tepung, dan bunga-bungaan yang mudah membentuk gumpalan jika kena panas.

2. Penyulingan dengan air dan uap air

Pada sistem penyulingan ini, memiliki keuntungan yaitu uap dapat berpenetrasi secara merata ke dalam jaringan bahan dan suhu dapat dipertahankan sampai $100^{\circ} \mathrm{C}$. Lama penyulingan relatif lebih singkat, rendemen minyak lebih besar, dan mutunya lebih baik jika dibandingkan dengan minyak hasil dari sistem penyulingan dengan air.

3. Penyulingan dengan uap air

Distilasi uap adalah suatu cara yang digunakan untuk memisahkan dan memurnikan senyawasenyawa organik. Distilasi uap hanya dapat dilakukan pada senyawa organik yang tidak larut dalam air dan mempunyai tekanan uap yang tinggi.

\section{METODOLOGI PENELITIAN}

Penelitian dilakukan melalui beberapa tahap.

1. Tahap pertama adalah Penyulingan Minyak Atsiri

Batang Sereh Batang sereh sebanyak 500 gram dicuci terlebih dahulu kemudian di potong kecilkecil dan diangin-anginkan hingga kering, setelah itu diblender sampai menjadi serbuk. Serbuk dimasukkan ke dalam toples kemudian di tambahkan air sebanyak 1,5 liter di aduk beberapa kali kemudian didiamkan dan dibiarkan selama 24 jam pada suhu kamar yang terlindung dari cahaya, sambil sekali-kali diaduk. Fitrat disaring kemudian diuapkan dengan suhu $1000{ }^{\circ} \mathrm{C}$ selama 3 jam sampai diperoleh ekstrak kental. Ekstrak yang diperoleh ditimbang beratnya yang didapat. Hasil kadar minyak atsiri kemudian ditambahkan sebagai zat aktif dalam lotion anti nyamuk. 
2. Tahap kedua Pembuatan Dasar Lotion

Hasil ekstraksi yaitu minyak atsiri akan ditambahkan sebagai bahan aktif dalam pembuatan lotion. Lotion yang dibuat dari 3 golongan bahan yaitu bahan A (Asam stearat) sebagai fasa minyak, bahan B (Aquadest, Gliserin, Trietanolamine, Metil paraben) sebagai fasa air, dan Minyak Atsiri sebagai bahan pelembab dengan Variasi jumlah kadar minyak atsiri dari $0 \%, 0,5 \%, 1 \%, 1,5 \%$, dan $2 \%$ dan kemudian di diamkan selama 5 hari. Dari lotion yang didapat akan dilakukan uji kualitas lotion yang berupa uji pH, uji viskositas, dan massa jenis pada standar SNI 16-4399-1996.

Tabel 2. Optimasi Lotion Anti Nyamuk dari variasi konsentrasi Minyak Atsiri (\%)

\begin{tabular}{|l|c|c|c|c|c|}
\hline \multicolumn{1}{|c|}{ Bahan } & $\begin{array}{c}\text { Formula 1 } \\
\%\end{array}$ & $\begin{array}{c}\text { Formula 2 } \\
\%\end{array}$ & $\begin{array}{c}\text { Formula 3 } \\
\%\end{array}$ & $\begin{array}{c}\text { Formula 4 } \\
\%\end{array}$ & $\begin{array}{c}\text { Formula 5 } \\
\%\end{array}$ \\
\hline Minyak Atsiri & 0 & 0,5 & 1 & 1,5 & 2 \\
\hline Gliserin & 2 & 2 & 2 & 2 & 2 \\
\hline Asam Stereat & 3 & 3 & 3 & 3 & 3 \\
\hline Metil Paraben & 0,1 & 0,1 & 0,1 & 0,1 & 0,1 \\
\hline Trietanolamin & 0,75 & 0,75 & 0,75 & 0,75 & 0,75 \\
\hline Aquadest & ad 100 & ad 100 & ad 100 & ad 100 & ad 100 \\
\hline
\end{tabular}

3. Metode Pengamatan

a. Pengamatan Bau Citronella dengan cara mencium bau yang paling kuat dari 5 formula tersebut.

b. Pengukuran $\mathrm{pH}$ (Derajat Keasaman)

Pengukuran $\mathrm{pH}$ dari formula lotion yang telah dibuat dengan menggunakan $\mathrm{pH}$ universal yang dilakukan selama 5 hari, dengan cara sebanyak 0.5 gram sediaan di encerkan dengan $5 \mathrm{~mL}$ aquades didalam beaker glass, kemudian indikator $\mathrm{pH}$ dicelupkan ke dalam larutan terseebut, ditunggu beberapa saat. Warna yang ditunjukkan $\mathrm{pH}$ universal merupakan $\mathrm{pH}$ dari sediaan tersebut. PH yang baik untuk kulit ialah 4.5 sampai dengan 8 .

c. Pengukuran Viskositas Lotion

Digunakan Viskometer Brookfiled karena viskometer ini dapat mengukur sedian yang bersifst Non Newton dan Newton. Prisip kerjanya dengan menggunakan spindel dan motor. Setelah motor dihidupkan maka spindel akan berputar dan diamati angka yang ditunjukan oleh jarum merah, dicatat. Utuk menghitung viskositasnya maka angka yang ditunjukan oleh jarum merah dikalikan dengan suatu faktor yang terdapat pada brosur alat. Penentuan viskositas bertujuan untuk mengetahui adanya perubahan kekentalan pada tiap formula lotion. Pengujian body lotion berdasarkan standar mutu SNI 16-4399-1996 bahwa viskositas body lotion berkisar antara 2000-5000cp.

d. Uji Iritasi

Uji ini dilakukan untuk memeriksa kepekaan kulit terhadap suatu bahan dilakukan terhadap sukarelawan selama 15 menit di punggung tangan. Kulit dikatakan teriritasi apabila terjadi pengkasaran atau gatal-gatal pada kulit sukarelawan. 
Pembuatan Minyak Atsiri Batang Sereh :

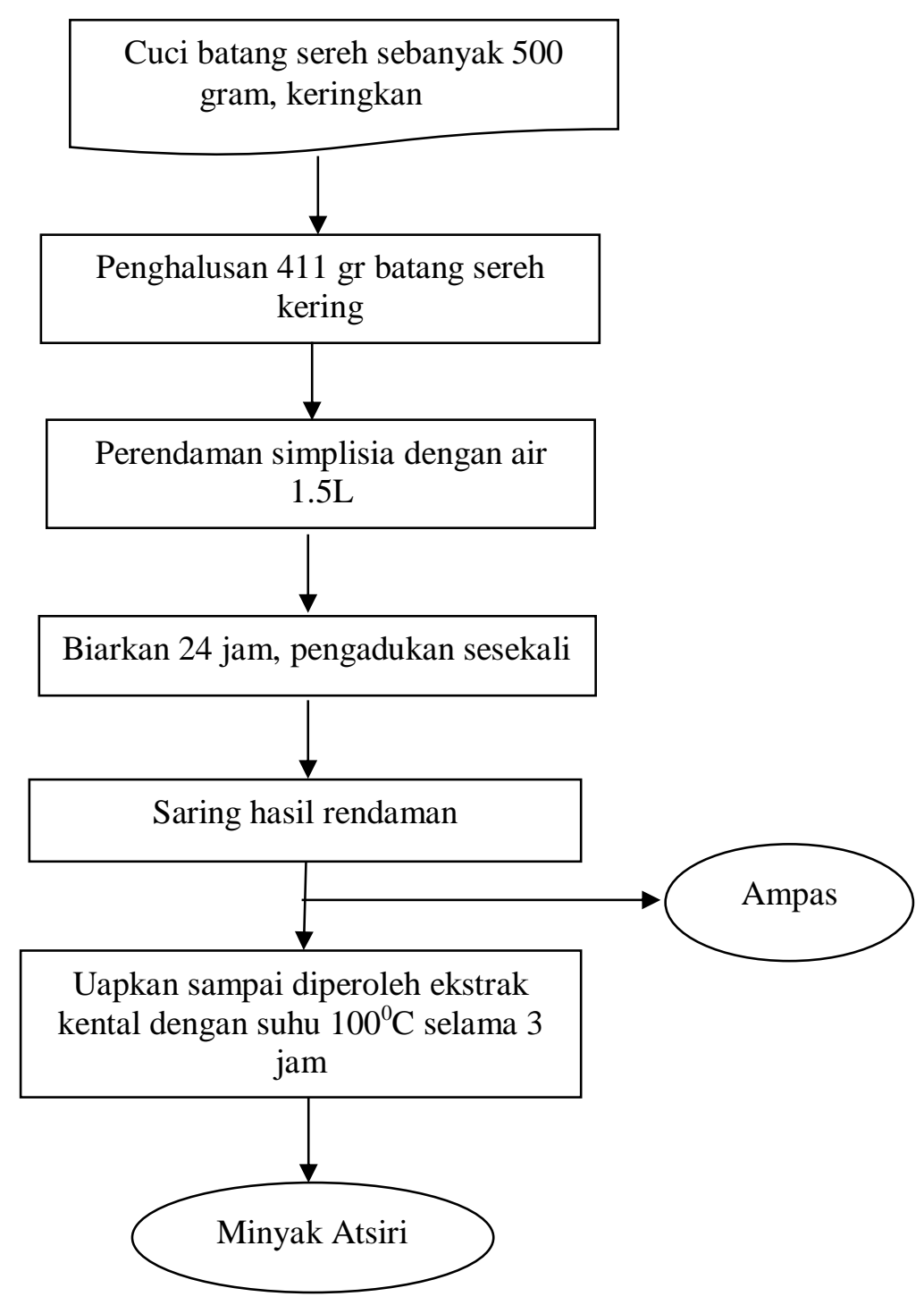

Gambar 1. Diagram alir pembuatan minyak atsiri batang sereh 
Pembuatan Lotion Minyak Atsiri Batang Sereh

Pemanasan asam stereat (Bagian A) sampai $70^{\circ} \mathrm{C}$, sebagai fase minyak
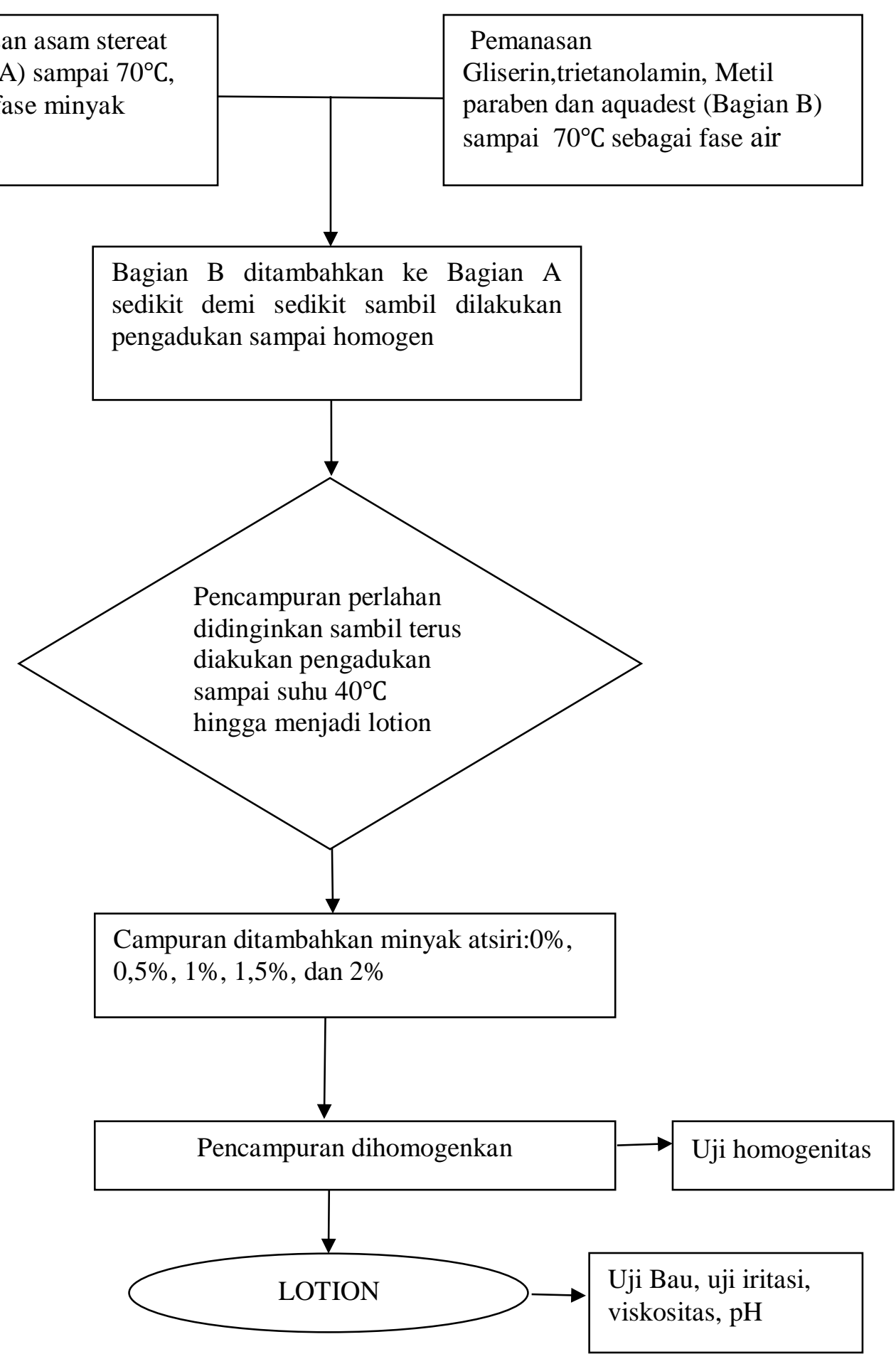

Gambar 2. Diagram Alir Pembuatan Lotion Minyak Atsiri Batang Sereh 


\section{HASIL DAN PEMBAHASAN}

\section{Data Pengamatan}

Dari hasil ekstraksi bahan simplisia sereh sebanyak 411 gram yang telah dipekatkan didapat Minyak Atsiri sebanyak 14,73 gram. Dari hasil tersebut maka peneliti menetapkan bahwa persentase Minyak atsiri yang dipakai $1 \%$ sebanyak 2 gram. Dan total dalam satu formula sebanyak 200 gram lotion. Untuk lebih jelasnya dapat dilihat dibawah ini:

Tabel 3. Kompoisi Formula lotion Anti Nyamuk dengan satuan Gram.

\begin{tabular}{|c|c|c|c|c|c|}
\hline Bahan & $\begin{array}{c}\text { Formula I } \\
(\text { Gram })\end{array}$ & $\begin{array}{c}\text { Formula II } \\
(\text { Gram })\end{array}$ & $\begin{array}{c}\text { Formula III } \\
(\text { Gram })\end{array}$ & $\begin{array}{c}\text { Formula IV } \\
(\text { Gram })\end{array}$ & $\begin{array}{c}\text { Formula V } \\
(\text { Gram })\end{array}$ \\
\hline MA & 0 & 1 & 2 & 3 & 4 \\
\hline Gliserin & 4 & 4 & 4 & 4 & 4 \\
\hline AS & 6 & 6 & 6 & 6 & 6 \\
\hline MP & 0,2 & 0,2 & 0,2 & 0,2 & 0,2 \\
\hline TEA & 1,5 & 1,5 & 1,5 & 1,5 & 1,5 \\
\hline Aquadest & 188,3 & 187,3 & 186,3 & 185,3 & 184,3 \\
\hline
\end{tabular}

Hasil Pengamatan Penelitian berdasarkan pengamatan Bau, Viskositas, Iritasi kulit, dan Pengukuran pH dijabarkan ditabel berikut ini :

Tabel 4. Hasil Pengamatan

\begin{tabular}{|c|c|c|c|c|c|c|}
\hline Formula & STD & I & II & III & IV & V \\
\hline Viscositas & $\begin{array}{c}2000- \\
50000 \mathrm{cp}\end{array}$ & 2100 & 2400 & 2600 & 2800 & 3000 \\
\hline Iritasi & - & Aman & Aman & Aman & Aman & Aman \\
\hline $\mathrm{pH}$ & $4,5-8$ & 5,6 & 6,3 & 6,6 & 6,8 & 6,9 \\
\hline $\mathrm{Bau}$ & - & $\begin{array}{c}\text { Tidak } \\
\text { Berbau }\end{array}$ & $\begin{array}{c}\text { Khas } \\
\text { Citronella }\end{array}$ & $\begin{array}{c}\text { Khas } \\
\text { Citronella }\end{array}$ & $\begin{array}{c}\text { Khas } \\
\text { Citronella }\end{array}$ & $\begin{array}{c}\text { Khas } \\
\text { Citronella }\end{array}$ \\
\hline
\end{tabular}

\section{Pembahasan}

\section{Viskositas}

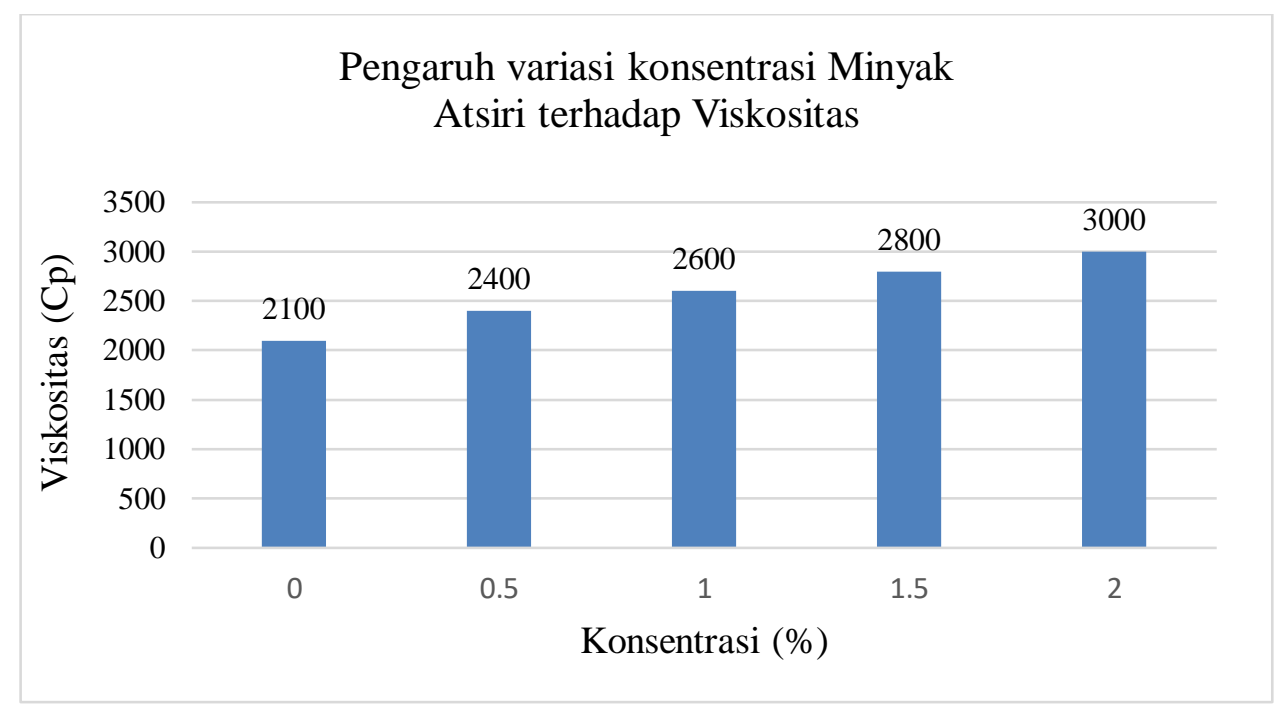

Gambar 3. Pengaruh Variasi Konsentrasi Minyak Atsiri Terhadap Viskositas 
Pada diagram dapat dilihat bahwa nilai viskositas cenderung meningkat dengan semakin tingginya kosentrasi dari minyak atsiri dengan nilai tertinggi pada formula V dengan nilai $3000 \mathrm{cp}$. Dari sini bisa ditarik kesimpulan dengan bertambahnya Zat Aktif pada formula lotion maka akan mempengarhui dari meningkatnya Viskositas. Hasil Viskositas lotion ini sesuai dengan standar SNI 16-4399-1996 yaitu berkisar antara 2000-50000 cPoise.

\section{Bau Citronella}

Pada pemeriksaan tersebut Formula I tidak berbau Citronella sedangkan Formula II, III, IV, dan V berbau Citronella ini disebabkan dari Minyak Atsiri yang di campur. Dan untuk warna Formula I berwarna putih, Formula II juga berwarna putih di sebabkan campuran Minyak Atsiri yang sedikit yaitu sebesar $0,5 \%$.

\section{3. $\mathbf{p H}$}

Pengukuran $\mathrm{pH}$ merupakan salah satu pengujian penting dan sering digunakan pada analisa air, $\mathrm{pH}$ merupakan faktor penting dalam menentukan sifat kimia dan biologi dalam air. Ini mempengaruhi bentuk kimia dan dampak lingkungan dari berbagai zat kimia dalam air. Nilai $\mathrm{pH}$ lotion minyak sereh wangi berkisar antara 5,9-7,2. Hasil sidik ragam membuktikan bahwa konsentrasi minyak sereh wangi berpengaruh terhadap pH. Menurut SNI 16-4399-1996, untuk produk pelembab kulit nilai pH sebaiknya berkisar antara 4,5-8,0.

\section{Iritasi}

Untuk uji iritasi dilakukan dengan cara mengoleskan krim kepada 10 orang, dan ternyata setelah di diamkan selama 15 menit tidak terjadi iritasi kulit pada panelis.

\section{KESIMPULAN}

1. Dengan ditambahkannya konsentrasi dari Minyak Atsiri dari sereh dapat mempengaruhi Viskositas lotion. Dan dari sini pula disimpulkan Minyak Atsiri dari batang sereh dapat dijadikan bahan tambahan dalam pembuatan lotion anti nyamuk.

2. Lotion anti nyamuk dari minyak sereh wangi yang dihasilkan berwarna putih kekuningan, berbau khas wangi sereh dan tidak menimbulkan iritasi terhadap kulit. Dan dari hasil penelitian untuk Formula V adalah yang terbaik itu dari konsentrasi sebanyak 2\% dan Viskositasnya sebesar 3000 cp.

\section{DAFTAR PUSTAKA}

Ayu asmoro ningrum.2011.Faktor faktor yang mempengaruhi pembentukan emulsi di antaranya,suhu, waktu pengadukan dan kecepatan pengadukan,skripsi, sarjana, Universitas Sanata dharma.

Cassel, Eduardo, dan Rubem M. F. Vargas, 2006, Experiments and Modeling of the Cymbopogon winterianus Essential Oil Extraction by Steam Distillation, Jurnal Operacoes Unitarias, Engineering Faculty,50(3), 126-129.

Eka, Adelia. 2018. Uji Organoleptik. www.acedemia.edu/12273406/uji organoleptik. Diakses tanggal 18 juli 2020. 
Fitriani, Eka., dkk, 2013, studi Efektivitas Ekstrak Daun Sereh Wangi (Cymbopogon nardus L.) Sebagai Anti Fungi Candida albicans, Jurnal Biocelebes, Vol. 7 No. 2.

Ketaren, S. 2008. Pengantar Teknologi Minyak Dan Lemak Pangan. Penerbit Universitas Indonesia, Jakarta

Schmitt, W. H. 1996. Skin Care Products. In : Williams, D. F. and W. H. Schmitt (Ed.). 1996.

Usmiati, Sri., Dkk, 2015, Limbah Penyulingan Sereh Wangi Dan Nilam Sebagai Insektisida Pengusir Lalat Rumah (Musca domestica). Jurnal teknik industri. 